\title{
PENGARUH PEMBERIAN SEDIAAN EMULGEL EKSTRAK BUAH MAHKOTA DEWA (PHALERIA MACROCARPA (SCHEFF). BOERL.) DAN EKSTRAK DAUN PEPAYA (CARICA PAPAYA L.) DENGAN KITOSAN SEBAGAI GELLING AGENT TERHADAP PENYEMBUHAN LUKA BAKAR
}

\author{
Yogie Irawan ${ }^{1}$ Novi Rimba Sari ${ }^{2}$ Risa Chandra Alfaninda ${ }^{3}$ \\ ${ }^{123}$ STIKes Borneo Cendekia Medika Pangkalan Bun \\ 1email : masyuduk@gmail.com,${ }^{2}$ email : novi.rimbasari92@ gmail.com, ${ }^{3}$ email: \\ risachandra19@gmail.com
}

\begin{abstract}
ABSTRAK
Pendahuluan: Sejumlah studi menunjukkan bahwa tanaman tradisional berpotensi sebagai agen penyembuhan luka bakar, buah mahkota dewa (Phaleria macrocarpa (Scheff). Boerl.) dan daun pepaya (Carica papaya L.). Metode penelitian: Subjek penelitianya adalah 20 ekor tikus yang dibagi dalam 4 kelompok, yaitu kelompok kontrol positif (+), kelompok kontrol negatif (-), kelompok kontrol formulasi buah mahkota dewa $10 \%$ dan daun pepaya $5 \%$, kelompok formulasi buah mahkota dewa $20 \%$ dan daun pepaya $10 \%$. Hasil dan pembahasan: Hasil penelitian ini menunjukkan bahwa setiap kontrol memberikan pengaruh terhadap penyembuhan luka bakar. Emulgel-kitosan ekstrak buah mahkota dewa dengan konsentrasi 20\% memiliki efek penyembuhan yang paling besar dengan presentase penyembuhan 95,43\% dibandingkan dengan emulgel-kitosan ekstrak buah mahkota dewa $10 \%$ $(77,3 \%)$, kontrol positif $(92,73 \%)$, dan kontrol negatif $(64,94 \%)$. Penelitian ini bertujuan untuk mengetahui pengaruh pemberian sediaan emulgel ekstrak buah mahkota dewa dengan kitosan sebagai gelling agent terhadap penyembuhan luka bakar pada tikus.
\end{abstract}

Kata Kunci: Emulgel, Buah mahkota dewa (Phaleria macrocarpa (Scheff). Boerl.), Daun Pepaya (Carica Papaya L.), Kitosan, Luka bakar, Penyembuhan luka.

THE EFFECT OF GIVING AN EMULGEL OF THE CROWN OF GODS EXTRACT (PHALERIA MACROCARPA (SCHEFF). BOERL.) AND PAPAYA LEAF EXTRACT (CARICA PAPAYA L.) WITH KITOSAN AS GELLING AGENT AGAINST HEALING BURNS

\begin{abstract}
A number of studies have shown that traditional plants have potential as agents for healing burns, the crown of the god (Phaleria macrocarpa (Scheff). Boerl.) And papaya leaves (Carica papaya L.). The research subjects were 20 rats divided into 4 groups, namely the positive control group (+), the negative control group (-), the control group of the god crown fruit formulation $10 \%$ and the papaya leaf 5\%, the crown god formulation group $20 \%$ and the leaves papaya $10 \%$. The results of this study indicate that each control has an influence on the healing of burns. Chitosan
\end{abstract}


emulgel extract of god crown fruit with a concentration of $20 \%$ has the greatest healing effect with a healing percentage of $95.43 \%$ compared with Emulgel-Chitosan crown extract of god crown fruit $10 \%$ (77.3\%), positive control $(92.73 \%)$, and negative control (64.94\%). The aim of this study was to determine the effect of the administration of emulgel extract of the Crown of God with chitosan as a gelling agent to burn burns in mice.

Keywords: Emulgel, god crown fruit (Phaleria macrocarpa (Scheff). Boerl.), Papaya Leaves (Carica Papaya L.), Chitosan, Burns, Wound healing.

\section{PENDAHULUAN}

Di Indonesia terdapat laporan mengenai jumlah penderita dan jumlah angka kematian yang diakibatkan karena luka bakar. Berdasarkan catatan WHO luka bakar menyebabkan 195.000 kematian per tahun diseluruh dunia terutama negara miskin dan berkembang. Penanganan pada penyembuhan luka bakar dapat dilakukan dengan cara mencegah infeksi sekunder, memacu pembentukan jaringan kolagen dan mengupayakan agar sisa-sisa sel epitel dapat berkembang sehingga dapat menutup permukaan luka.

Untuk proses penyembuhan pada luka bakar dibagi dalam 3 fase, yaitu fase inflamasi, poliferasi, dan maturasi. Fase inflamasi berlangsung sejak awal terjadinya luka bakar sampai hari ke-5, fase poliferasi umumnya dapat berlangsung mulai dari hari ke- 4 setelah terjadi luka bakar dan fase maturasi dapat berlangsung mulai dari hari ke- $21^{1}$.

Penanganan pada penderita luka bakar, salah satunya dengan menggunakan sediaan topikal. Pemberian sediaan topikal yang tepat serta efektif, dapat diharapkan mengurangi dan mencegah infeksi pada luka. Sediaan topikal yang dipilih pada penelitian kali ini adalah sediaan emulgel. Emulgel adalah sediaan emulsi tipe minyak/air atau air/minyak yang digelkan dengan adanya penambahan gelling agent didalamnya ${ }^{2}$. Kelebihan gel yaitu dapat memberikan rasa dingin di kulit, karena adanya kandungan air yang cukup tinggi sehingga nyaman digunakan. Pada emulsi terdapat fase minyak yang berfungsi sebagai emolien yang akan mencegah penguapan, sehingga kandungan air di dalam kulit dapat dipertahankan ${ }^{3}$.

Obat-obatan herbal banyak digunakan sebagai alternatif pengobatan karena toksisitas lebih rendah dibanding obatobatan kimia. Penggunaan obat herbal untuk perawatan luka bakar akan sangat membantu masyarakat, tanaman obat herbal yang digunakan adalah buah mahkota dewa dan daun pepaya, karena harganya yang murah, mudah untuk ditanam dan dipelihara. Zat aktif yang terkandung di dalam buah mahkota dewa antara lain, Alkaloid, Saponin, Lignan (polifenol),dan Flavonoid yang memiliki efek sebagai antibakteri dan sebagai antiinflamasi ${ }^{4}$. Berdasarkan uraian diatas, maka akan dilakukan penelitian tentang formulasi emulgel ekstrak buah mahkota dewa dengan gelling agent (GA) kitosan dan emulgel ekstrak daun pepaya dengan gelling agent (GA) kitosan untuk mengatasi luka bakar pada tikus yang dilukai logam panas.

\section{METODE PENELITIAN}

Kategori penelitian yang dilakukan dalam penelitian ini adalah true 
experimental laboratories dengan rancangan pre posttest only control group design.

\section{Alat Penelitian}

Alat yang digunakan pada penelitian kali ini adalah timbangan analitik(Mettler toledo®), ayakan mesh 200 (Retsch®), alat gelas (Iwaki TE-32 Pirex ${ }^{\circledR}$ Japan), wadah gel, kandang hewan, kompor listrik (Maspion $®)$, pencukur bulu (Gillette $\AA$ ), jangka sorong (Sellery®), lempeng logam, blender (Philps®), alat uji daya lekat, alat uji daya sebar, kertas saring, dan waterbath (Memmert $\left.{ }^{\circledR}\right)$.

\section{Bahan Penelitian}

Bahan yg digunakan Simplisia buah Mahkota dewa, kitosan (PT.Biochitosan $\left.{ }^{\circledR}\right)$, bahan pembanding bioplacenton salep (Kalbe Farma), bahan kimia habis pakai Etanol $70 \%$ (Brataco®), propilenglikol (Brataco®), aquadest (Brataco®), VCO (Brataco®), tween $80 \quad$ (Brataco®), span 80 (Brataco®), Carbomer (Brataco®), $\mathrm{NaoH}$ (Brataco $\left.{ }^{\circledR}\right), \mathrm{KOH}$ (Brataco®), HCL (Brataco®), Mg (Brataco®), $\mathrm{FeCL}_{3}$ (Brataco®). Hewan uji tikus putih betina tidak hamil, usia \pm 2 bulan, berat $180-200$ gram, galur Wistar.

\section{Pembuatan ekstrak buah mahkota dewa dan daun pepaya}

Serbuk simplisia sebanyak $1 \mathrm{~kg}$ ditambahkan Etanol 70\%, dibiarkan selama 5 hari sambil diaduk berulangulang. Ekstrak disaring dengan kertas saring dan diuapkan menggunakan Waterbath pada suhu $60^{\circ} \mathrm{C}$ sampai alkohol hilang ${ }^{5}$. Proses penyarian zat aktif pada penelitian ini dilakukan menggunakan metode maserasi. Proses ekstraksi dilakukan dengan cara merendam $1 \mathrm{~kg}$ serbuk daun pepaya (Carica papaya L.) dengan pelarut etanol $70 \%$. Proses maserasi dilakukan selama 5 hari dengan bantuan pengadukan. Setelah proses maserasi, tahapan selanjutnya adalah proses pemekatan dengan cara dipanaskan hingga kental.

\section{Skrining fitokimia}

Skrining fitokimia dilakukan dengan mengidentifikasi kandungan flavonoid, saponin, alkaloid dan polifenol.

\section{Pembuatan formula emulgel}

Pembuatan gelling agent kitosan

Sebanyak 2 gram serbuk kitosan dilarutkan dalam $100 \mathrm{ml}$ asam asetat $1 \%$ kemudian diaduk dan dipanaskan pada suhu $70^{\circ} \mathrm{C}$.

Pembuatan emulgel

Ekstrak Buah Mahkota Dewa (Phaleria Macrocarpa (Scheff).Boerl) Dengan Galling Agent Kitosan

Menimbang bahan-bahan yang diperlukan seperti yang tertera pada tabel 1, pembuatan emulgel diawali dengan pembuatan fase air yaitu dimasukan ekstrak buah mahkota dewa, gelling agent kitosan ditambah carbomer dan propilenglikol setelah itu digerus hingga homogen. Pada fase minyak, VCO ditambahkan emulgator span 80 dan tween 80 dimasukkan dalam mortir yang lain dan digerus hingga homogen. Kemudian fase air dan fase minyak dicampur menjadi satu dan digerus hingga homogen. Sampai terbentuk sediaan emulgel ekstrak buah mahkotadewa (Phaleria macrocarpa (Scheff).Boerl). 
Pembuatan emulgel ekstrak daun papaya (Carica papaya L.) dengan gelling agent kitosan

Menimbang bahan-bahan yang diperlukan seperti yang tertera pada tabel 2, pembuatan emulgel diawali dengan pembuatan emulsi fase minyak emulsi dibuat dengan cara span 80 dilarutkan dengan ekstrak dan VCO. Fase air emulsi tween 80, Fase minyak dan air dipanaskan secara terpisah. Kemudian fase air dimasukan ke dalam fase minyak dan diaduk sambil dipanaskan. Pembuatan gel dibuat dengan cara basis karbopol digerus sampai homogen ditambah dengan kitosan sedikit demi sedikit lalu masukan propilenglikol. Pembuatan emulgel dari hasil pembuatan emulsi dan gel tadi dicampur jadi satu digerus hingga homogen hingga terbentuk sediaan emulgel ekstrak daun pepaya (Carica papaya L.).

Formulasi emugel kitosan-ekstrak buah mahkota dewa

Tabel 1. Formulasi sediaan emulgel kitosan ekstrak buah mahkotadewa (Phaleria macrocarpa (Scheff).Boerl).

\begin{tabular}{cccc}
\hline Bahan & \multicolumn{3}{c}{ Konsentrasi b/v \% } \\
\cline { 2 - 4 } & $\begin{array}{c}\text { Placeb } \\
\text { o }\end{array}$ & F1 & F2 \\
\hline Ekstrak buah & - & $10 \%$ & $20 \%$ \\
mahkota & & & \\
dewa & & & \\
Kitosan & $2 \%$ & $2 \%$ & $2 \%$ \\
Propilengliko & $5 \%$ & $5 \%$ & $5 \%$ \\
1 & & & \\
VCO & $5 \%$ & $5 \%$ & $5 \%$ \\
Tween 80 & 0,616 & 0,616 & 0,616 \\
& $\%$ & $\%$ & $\%$ \\
Span 80 & 2,384 & 2,384 & 2,384 \\
& $\%$ & $\%$ & $\%$ \\
Karbopol & $17,4 \%$ & $15,4 \%$ & $13,4 \%$ \\
Add & 100 & 100 & 100 \\
\hline
\end{tabular}

Formulasi gel kitosan ekstrak daun pepaya (Carica papaya L.)

Tabel 2. Formulasi sediaan gel kitosan ekstrak daun papaya (Carica papaya L.)

\begin{tabular}{cccc}
\hline \multirow{2}{*}{ Bahan } & \multicolumn{3}{c}{ Formula dan Komposisi } \\
& \multicolumn{3}{c}{$(\% \mathrm{~b} / \mathrm{v})$} \\
\cline { 2 - 4 } & $\begin{array}{c}\text { Formula } \\
\text { Formula }\end{array}$ & $\begin{array}{c}\text { Plas } \\
\text { ebo }\end{array}$ \\
\hline Ekstrak & $5 \%$ & $10 \%$ & - \\
daun & & & \\
papaya & & & \\
Kitosa & $73,8 \%$ & $69,3 \%$ & 69,3 \\
n & & & $\%$ \\
Propil & $5 \%$ & $5 \%$ & $5 \%$ \\
englikol & & & \\
VCO & $5 \%$ & $5 \%$ & $5 \%$ \\
Tween & $0,016 \%$ & $0,616 \%$ & 0,61 \\
80 & & & $6 \%$ \\
Span & $2,384 \%$ & $2,384 \%$ & 2,38 \\
80 & & & $4 \%$ \\
Carbo & $3,85 \%$ & $7,7 \%$ & 7,7 \\
pol & & & $\%$ \\
Aquad & $100 \%$ & $100 \%$ & 100 \\
est ad & & & $\%$ \\
\hline
\end{tabular}

\section{Analisa Data}

Data yang diperoleh dari penelitian ini berupa diameter luka $(\mathrm{cm})$ yang diukur dengan jangka sorong. Diameter luka bakar yang diperoleh dihitung dengan menggunakan rumus:

$\mathrm{dx}=\frac{d 1+d 2+d 3}{3}$.

Ket :

$\mathrm{dx}$ : diameter pada hari ke $\mathrm{x}$

$\mathrm{dx}(1,2,3)$ : diameter luka bakar dalam berbagai arah

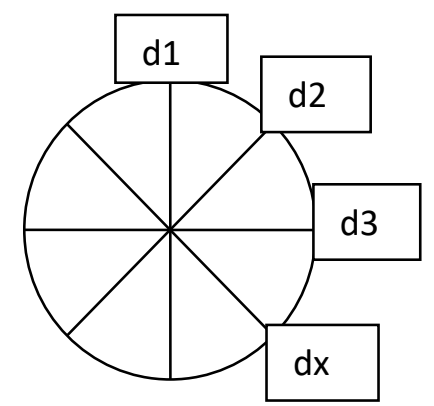


Gambar 1. Cara mengukur diameter luka bakar

Kemudian hitung presentasi penyembuhan luka bakar dengan rumus berikut

$\mathrm{P} \%=\frac{d o-d x}{d o} \times 100 \%$.

Ket :

$\mathrm{P} \%=$ Presentasi penyembuhan luka bakar pada hari ke $\mathrm{x}$

do = Diameter luka bakar awal

$\mathrm{dx}=$ Diameter luka bakar pada hari pengamatan

Data yang diperoleh dari rumus 1 dan rumus 2 di analisa dengan uji normalitas yaitu Shapiro-Wilk 2 test $p$ $>$ 005). Data berdistribusi normal dilanjutkan analisis parametik (ANOVA) dan apabila data berdistribusi tidak normal dilakukan uji non parametik. Uji ANOVA untuk mengetahui perbedaan KI, KII, KIII, dan KIV terhadap penyembuhan luka bakar pada tikus.

\section{HASIL PENELITIAN}

\section{Pengujian skrining fitokimia}

Kandungan dalam ekstrak buah mahkota dewa (Phaleria macrocarpa (Scheff). Boerl.) diidentifikasi dengan cara skrining fitokimia. Kandungan senyawa yang diuji antara lain golongan Alkaloid, Saponin, Lignan (Polifenol), dan Flavonoid.

Tabel 3. Hasil Skrining Fitokimia Ekstrak Buah Mahkota Dewa

\begin{tabular}{llc}
\hline $\begin{array}{l}\text { Kandungan } \\
\text { kimia }\end{array}$ & $\begin{array}{l}\text { Hasil } \\
\text { Skrining } \\
\text { Fitokimia }\end{array}$ & $\begin{array}{l}\text { Ketera } \\
\text { ngan }\end{array}$ \\
\hline Alkaloid & Terdapat & + \\
Saponin & endapan & + \\
Lignan & Terdapat & + \\
(Polifenol) & busa & + \\
Flavonoid & Berwarna & \\
& hitam & \\
& Berwarna & \\
& jingga tua & \\
\hline
\end{tabular}

Keterangan : (+) memberikan hasil positif

Tabel 4. Hasil Identifikasi ekstrak daun pepaya (Carica papaya L.)

\begin{tabular}{|c|c|c|c|}
\hline No & $\begin{array}{l}\text { Kan } \\
\text { dung } \\
\text { an } \\
\text { Kimi } \\
\text { a }\end{array}$ & $\begin{array}{l}\text { Hasil } \\
\text { Identifikasi }\end{array}$ & $\begin{array}{l}\text { Ket } \\
\text { era } \\
\text { nga } \\
n\end{array}$ \\
\hline 1. & $\begin{array}{l}\text { Alka } \\
\text { loid }\end{array}$ & $\begin{array}{l}\text { Dragendrof } \\
: \quad \text { Endapan } \\
\text { merah bata }\end{array}$ & + \\
\hline 2. & $\begin{array}{l}\text { Flav } \\
\text { onoi } \\
\text { d }\end{array}$ & $\begin{array}{l}\text { Terbentuk } \\
\text { warna } \\
\text { merah } \\
\text { kecoklatan }\end{array}$ & + \\
\hline 3. & $\begin{array}{l}\text { Sapo } \\
\text { nin }\end{array}$ & $\begin{array}{l}\text { Terdapat } \\
\text { buih yang } \\
\text { stabil }\end{array}$ & + \\
\hline
\end{tabular}

Keterangan: + : menunjukkan hasil positif

Berdasarkan hasil penelitian yang dilakukan maka dapat disimpulkan bahwa hasil uji skrining fitokimia menunjukan ekstrak buah mahkota dewa (Phaleria macrocarpa (Scheff). Boerl.) positif mengandung senyawa Alkaloid, Saponin Polifenol dan Flavonoid dan ekstrak daun pepaya (Carica papaya L.) positif 
mengandung senyawa golongan alkoloid, Saponin dan Flavinoid

\section{Hasil uji efektifitas luka bakar pada tikus}

Tabel 5. Rata-rata presentase diameter penyembuhan luka bakar (mm)

\begin{tabular}{lllllll}
$\begin{array}{l}\text { Kelomp } \\
\text { ok }\end{array}$ & Ha & Ha & Ha & Ha & Ha & Px \\
& ri 3 & ri 7 & ri & ri & ri & \\
& & & 11 & 15 & 21 & \\
\hline
\end{tabular}

$\begin{array}{lllllll}\text { Kontrol } & 13, & 12, & 12, & 4,2 & 0, & 92 \\ \text { Positif } & 13 & 56 & 24 & 6 \pm & 95 & 73 \\ & \pm 0, & \pm 3, & \pm 1, & 3,1 & \pm 0 & \pm 1 \\ & 16 & 69 & 95 & 0 & , 1 & 12^{\mathrm{b}} \\ & & & & & 3 & \end{array}$

Kontrol 14, 17, 13, 6,2 5, 64, $\begin{array}{lllllll}\text { Negatif } & 42 & 39 & 40 & 7 \pm & 07 & 94\end{array}$ $\pm 0, \quad \pm 3, \quad \pm 0, \quad 1,1 \quad \pm 0 \quad \pm 3$, $\begin{array}{llllll}78 & 69 & 73 & 0 & , 7 & 49^{\mathrm{a}}\end{array}$

Emulgel 17, 15, 14, 10, 4, 77, $\begin{array}{lllllll}10 \% & 92 & 41 & 81 & 14 & 05 & 3 \pm\end{array}$ $\pm 1, \quad \pm 1 . \quad \pm 1, \quad \pm 4, \quad \pm 0 \quad 1,0$

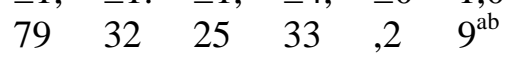

Emulgel 22, 14, 14, 9,6 0, 95, $\begin{array}{lllllll}20 \% & 29 & 10 & 10 & 7 \pm & 77 & 43\end{array}$ $\pm 3, \quad \pm 3, \quad \pm 3, \quad 1,3 \quad \pm 0 \quad \pm 0$, $\begin{array}{llllll}70 & 98 & 98 & 3 & , 0 & 70^{\mathrm{b}}\end{array}$

Hasil uji ANOVA terhadap efektifitas emulgel kitosan ekstrak buah mahkota dewa menunjukkan nilai $\mathrm{F}$ hitung $(159,860)>\mathrm{F}$ tabel $(4,07)$. Hasil ini menunjukkan adanya perbedaan efektifitas penyembuhan luka bakar antar kelompok uji $(p<0,05$.

Hasil uji LSD terhadap efektifitas emulgel kitosan ekstrak buah mahkota dewa menunjukkan adanya perbedaan antar tiap kelompok perlakuan. Kontrol positif berbeda signifikan dibanding kontrol negatif dan emulgel $10 \%$ $(p<0,05)$, namun tidak berbeda signifikan dengan emulgel $20 \%$ $(p>0,05)$. Kontrol negatif berbeda signifikan dibanding kontrol positif, emulgel $10 \%$ dan emulgel $20 \%$ $(p<0,05)$, Emulgel $10 \%$ berbeda signifikan dibanding dengan kontrol positif, kontrol negatif dan emulgel $20 \% \quad(p<0,05)$. Emulgel $20 \%$ tidak berbeda signifikan dibanding kontrol positif $(p>0,05)$, namun berbeda signifikan dengan kontrol negatif dan emulgel $10 \%(p<0,05)$.

Rata-rata persentase kesembuhan yang tertera pada tabel 5 menunjukkan kontrol positif sebesar 92,73 $\pm 1,12$, kontrol negatif sebesar 64,94 $\pm 3,49$, emulgel $10 \% 77,3 \pm 1,09$, dan emulgel $20 \% 95,43 \pm 0,70$. Dari data tersebut ternyata dapat disimpulkan bahwa emulgel 20\% sangat efektif dibandingkan dengan kontrol negatif dalam proses penyembuhan luka bakar.

Pada penelitian ini, pemberian emulgel dilakukan dua kali sehari pagi dan sore selama 21 hari. Pengamatan hari ke 3, luka bakar yang diberi emulgel ekstrak buah mahkota dewa 20\%, 10\%, Placebo dan Bioplacenton pada punggung tikus terlihat bahwa tepi luka berwarna kemerahan.

Pengamatan pada hari ke 7 luka bakar pada tikus terdapat nekrosis, namun luka bakar tikus yang diberi emulgel $10 \%$ dan $20 \%$ nekrosis mulai pengalami pengelupasan. Terbentuk nekrosis karena perubahan protein pada lapisan kulit yang terjadi pada daerah yang mengalami kerusakan. Nekrosis yang terbentuk diatas permukaan luka membantu mencegah luka terkontaminasi oleh mikroorganisme ${ }^{6}$. 
Pengamatan hari ke 11 dan 15 nekrosis pada masing masing tikus telah terkelupas dan pengelupsan nekrosis menandakan proses penyembuhan luka bakar memasuki epitalisasi. Epitalisasi adalah proses perbaikan sel-sel epitel kulit sehingga luka akan menutup. Pada hari ke 21 kesembuhan luka bakar pada masing masing kelompok tikus sudah terlihat. Pada emulgel ekstak buah mahkota dewa $10 \%$ telah mengalami kesembuhan namun bulu belum tumbuh, pada emulgel ekstrak buah mahkota dewa $20 \%$ bekas luka hampir tidak terlihat namun bulu belum tumbuh, pada kontrol negatif bekas luka masih tampak sedangkan pada kontrol positif bekas luka sudah tidak terlihat dan bulu sudah mulai tumbuh.

Efektifitas emulgel-kitosan ekstrak buah mahkota dewa (Phaleria macrocarpa (Scheff).Boerl) dalam penyembuhan luka bakar disebabkan berbagai senyawa dalam buah mahkota dewa, dimana buah mahkota dewa memiliki kandungan Saponin, Alkaloid, Polifenol dan Flavonoid. Saponin memiliki kemampuan sebagai pembersih dan antiseptik yang berfungsi membunuh kuman atau mencegah pertumbuhan mikroorganisme yang biasa timbul pada luka sehingga tidak mengalami infeksi. Sedangkan Alkaloid memiliki kemampuan sebagai antibakteri, yang diduga mengganggu komponen penyusup peptidoglikan pada sel bakteri, sehingga lapisan dinding sel tidak terbentuk secara utuh dan menyebabkan kematian sel tersebut. Selain itu, flavonoid memiliki efek antiinfalamasi yang berfungsi sebagai anti radang dan mampu mencegah kekakuan dan nyeri ${ }^{1}$.
Tabel 6. Hasil rata-rata diameter luka (mm)

\begin{tabular}{lllllll}
\hline Kelo & Ha & Ha & Ha & H & H & Px \\
mpok & ri 1 & ri 5 & ri & ari & ari & \\
& & & 11 & 15 & 18 & \\
\hline Kontr & 15, & 16, & 11, & 4, & 2, & 83 \\
ol (+) & 58 & 00 & 40 & 56 & 49 & 44 \\
& \pm & \pm & \pm & \pm & \pm & \pm \\
& 2,0 & 2,1 & 3,9 & 3, & 1, & 13 \\
& 6 & 5 & 0 & 22 & 79 & $48^{\mathrm{b}}$ \\
Kontr & 15, & 15, & 14, & 6, & 8, & 45 \\
ol (-) & 98 & 98 & 11 & 65 & 62 & 59 \\
& \pm & \pm & \pm & \pm & \pm & \pm \\
& 1,2 & 1,2 & 2,4 & 1, & 3, & 24 \\
& 8 & 8 & 5 & 04 & 79 & $13^{\mathrm{a}}$ \\
& & & & & & \\
F5\% & 16, & 16, & 16, & 8, & 3, & 81 \\
& 39 & 09 & 39 & 99 & 40 & 04 \\
& \pm & \pm & \pm & \pm & \pm & \pm \\
& 2,7 & 0,9 & 2,7 & 2, & 3, & 17 \\
& 8 & 0 & 8 & 49 & 02 & $03^{\mathrm{b}}$ \\
& & & & & & \\
F10\% & 13, & 15, & 11, & 6, & 0, & 93 \\
& 59 & 14 & 95 & 10 & 89 & 13 \\
& \pm & \pm & \pm & \pm & \pm & \pm \\
& 0,2 & 1,6 & 0,9 & 2, & 0, & 6,8 \\
& 9 & 3 & 5 & 56 & 88 & $7^{\mathrm{b}}$ \\
\hline
\end{tabular}

Keterangan : Notasi huruf $\left({ }^{a},{ }^{b}\right)$ yang berbeda pada kolom yang sama menunjukan berbeda signifikan pada setiap perlakuan pada uji LSD

Dilihat dari rata-rata persentase kesembuhan kontrol (-) sebesar 45,59 $\pm 24,13 \mathrm{~mm}$ berbeda signifikan dibanding kelompok kontrol (+), F5\% dan $\mathrm{F} 10 \%$. Hal tersebut menunjukan bahwa persentase kesembuhan paling optimal terjadi pada perlakuan kelompok emulgel ekstrak daun pepaya (Carica papaya L.) dengan konsentrasi F10\% dimana persentase kesembuhannya sangat efektif. Pada perlakuan kelompok kontrol (-) memberikan hasil penyembuhan yang paling lama jika dilihat dari rata-rata 
lebih kecil dibandingkan dengan kelompok perlakuan lainnya karena kontrol (-) tidak mengandung zat aktif daun pepaya (Carica papaya L.) melainkan hanya menggunakan basis gelling agent kitosan.

Hasil uji ANOVA terhadap efektifitas emulgel-kitosan ekstrak daun pepaya (Carica papaya L.) menunjukan nilai $\mathrm{F}$ hitung $(4,759)>F$ tabel $(4,07$; Lampiran 3). Hasil ini menunjukan adanya perbedaan efektifitas penyembuhan luka bakar antar kelompok uji ( $p<0,05$; Lampiran 3), sehingga $\mathrm{H} 0$ ditolak $\mathrm{H} 1$ diterima.

Hasil uji LSD terhadap efektifitas emulgel-kitosan ekstrak daun pepaya (Carica papaya L.) menunjukan ada perbedaan antar tiap perlakuan. Kelompok kontrol (+) berbeda signifikan lebih tinggi dibanding kontrol $(-) \quad(p<0,05)$, namun tidak berbeda signifikan dengan $\mathrm{F} 5 \%$ dan F10\% $(p>0,05)$. Tidak ada perbedaan antara kontrol (+) terhadap F5\% dan F10\% menunjukan efek penyembuhan luka bakar antara F5\% dan $\mathrm{F} 10 \%$ memiliki efek setara dengan kontrol (+). F5\% sudah memiliki efektifitas yg sama ditambah lagi dengan $\mathrm{F} 10 \%$ memiliki nilai yang lebih tinggi efektifitasnya dari kontrol (+).

Kontrol (-) memiliki perbedaan yang signifikan lebih rendah dibanding semua kelompok kontrol (+), F5\% dan F10\% dengan nilai signifikasinya $(p<0,05)$. Kelompok kontrol (-) menunjukan penyembuhan luka bakarwalaupun penyembuhannya kurang efektif daripada perlakuan pada kelompok perlakuan F5\% dan F10\%.

Kelompok F5\% berbeda signifikan lebih rendah dibanding kontrol (-) $(p<0,05)$. Namun tidak berbeda signifikan dengan kelompok kontrol
(+) dan $\mathrm{F} 10 \%$ karena nilai signifikannya $(p>0,05)$.

Kelompok F10\% berbeda signifikan lebih rendah dibanding K- dengan nilai signifikannya $(p<0,05)$ dan tidak memiliki perbedaan signifikan terhadap $\mathrm{K}+$ dan F5\% $(p>0,05) . \mathrm{F} 10 \%$ lebih efektif penyembuhannya dilihat dari persentase penurunan luka bakar, penyembuhannya lebih tinggi dari pada F5\% yaitu 93,13 $\pm 6,87$. Hal tersebut dimungkinkan karena F10\% memiliki konsentrasi ekstrak yang lebih tinggi daripada F5\% sehingga penyembuhannya terhadap luka bakar sangat efektif.

Pemberian bioplacenton bila dibandingkan dengan luka tanpa perlakuan memberikan hasil berbeda bermakna dimana berarti bioplacenton dapat membantu penurunan diameter luka. Bioplacenton bila dibandingkan dengan $\mathrm{F} 5 \%$ menghasilkan hasil berbeda tidak bermakna, artinya baik bioplacenton atau F5\% sama-sama membantu penurunan diameter luka. Bioplacenton bila dibandingkan dengan F10\% tidak memiliki perbedaan bermakna artinya adalah antara bioplacenton atau F10\% sama-sama membantu penurunan diameter luka. Pada penelitian Pitoyo (2013) menjelaskan bahwa bioplacenton memiliki kandungan yaitu neomysin sulfat $0,5 \%$ yang berperan sebagai antibiotik dan ekstrak plasenta sebagai stimulator dalam regenerasi sel, ini terbukti dengan rata-rata penyembuhan luka pada kelompok ini lebih tinggi daripada kontrol (-). Bahan yang berfungsi untuk pertumbuhan dan perkembangan sel kulit dan mempercepat proliferasi sel pada bioplacenton adalah ekstrak placenta $10 \%$. 
Berdasarkan hasil penelitian emulgel ekstrak daun pepaya (Carica papaya L.) konsentrasi $\mathrm{F} 10 \%$ memiliki efektifitas yang tinggi daripada kelompok kontrol yang lain dalam proses penyembuhan luka. Berdasarkan penelitian Ruswanti et.al (2014) kandungan flavonoid dapat mencegah pembentukan radikal bebas dan meminimalisir luka akibat reaksi oksidasi. Jenis fitokimia lain yang terkandung dalam daun pepaya (Carica papaya L.) yaitu saponin yang berguna untuk memicu pembentukan kolagen yang berperan dalam proses penyembuhan luka, papain berguna sebagai antiinflamasi dan antiedema.

Daun pepaya (Carica papaya L.) juga mempunyai daya kerja sebagai antimikroba. Menurut penelitian Januarsih Iwan dan Nur Atik (2010) pemberian ekstrak daun pepaya(Carica papaya L.) dapat mempercepat regenerasi epidermis dan granulasi jaringan pada luka sayat kulit mencit (Mus musculus). Daun pepaya (Carica papaya L.) banyak mengandung substansi penting untuk tubuh, diantaranya vitamin $\mathrm{C}$ dan $\mathrm{E}$, serta beta karoten yang berfungsi sebagai antioksidan yang dapat menetralisir radikal bebas hasil fagositosis neutrofil terhadap debris dan bakteri pada proses penyembuhan luka (proses respiratory burst).

Daun pepaya (Carica papaya L.) yang dilarutkan dengan etanol efektif dalam menghasilkan jumlah bahan aktif yang optimal sebagai obat penyembuh luka, serta tidak mudahditumbuhi jamur. Ekstrak etanol daun pepaya (Carica papaya L.) sebagai obat luka dibuat dalam bentuk emulgel akan mempermudah dalam pemakaiannya sehingga pengobatan lebih efektif
Dari penelitian ini didapatkan bahwa emulgel ekstrak daun pepaya (Carica papaya L.) merupakan salah satu terapi yang memiliki efektifitas terhadap penyembuhan luka bakar pada tikus putih (Rattus norvegicus). Hal ini dikarenakan beberapa senyawa yang terdapat di dalam ekstrak etanol daun pepaya (Carica papaya L.) mempunyai kemampuan dalam mempercepat regenerasi jaringan, re-epitelisasi dan pembentukan kolagen pada kulit yang terkena luka bakar serta memiliki efek antimikroba yang akan menekan mikroorganisme yang bisa memperlambat penyembuhan luka.

Berdasarkan uji efektivitas penyembuhan luka disimpulkan bahwa apabila dibandingkan dengan diberikan perlakuan kontrol (-), emulgel konsentrasi $\mathrm{F} 5 \%$ dan $\mathrm{F} 10 \%$ memberikan pengaruh pada penyembuhan luka dan peningkatan regenerasi sel kulit pada tikus putih (Rattus norvegicus).

\section{KESIMPULAN DAN SARAN \\ Kesimpulan}

Emulgel Ekstrak Buah Mahkota Dewa (Phaleria Macrocarpa (Scheff). Boerl) Dengan Kitosan Sebagai Gelling Agent

Berdasarkan hasil penelitian dapat diambil kesimpulan bahwa :

1. Didapatkan formula sediaan emulgel ekstrak buah mahkota dewa (Phaleria macrocarpa (Scheff). Boerl) dengan kitosan sebagai gelling agent yang efektif dalam penyembuhan luka bakar.

2. Efektifitas sediaan emulgel ekstrak buah mahkota dewa (Phaleria macrocarpa (Scheff). Boerl) dengan 
kitosan sebagai gelling agent terhadap penyembuhan luka bakar adalah konsentrasi $20 \%$ dengan rata-rata presentase kesembuhan luka bakar 95,43\%.

\section{Emulgel Ekstrak Daun Pepaya (Carica Papaya L.) Dengan Kitosan Sebagai Gelling Agent}

Berdasarkan hasil penelitian dapat disimpulkan bahwa :

1. Pemberian sediaan emulgel emulgel ekstrak daun pepaya (Carica papaya 1.) dengan gelling agent kitosan memiliki pengaruh terhadap penyembuhan luka bakar pada tikus yang di induksi panas.

2. Proses penyembuhan luka sangat efektif dengan menggunakan sediaan emulgel ekstrak daun pepaya (Carica papaya 1.) $10 \%$ dengan persentase rata-rata penyembuhan sebesar 93,12 lebih besar dari pada menggunakan sediaan emulgel ekstrak daun pepaya (Carica papaya 1.) $5 \%$ dengan persentase rata-rata penyembuhan sebesar 81,04.

\section{Saran}

Berdasarkan hasil penelitian maka diajukan saran yaitu :

1. Sebagai alternatif obat yang bersumber dari alam untuk penyembuhan luka bakar.

2. Perlu adanya penelitian lanjutan dengan konsentrasi ekstrak yang bervariasi untuk memperoleh efek yang optimal terhadap penyembuhan luka bakar.

\section{DAFTAR PUSTAKA}

Mawarsari, T., 2015. Uji Aktivitas Penyembuhan Luka Bakar Ekstrak Etanol Umbi Talas Jepang (Colocasia esculenta (L) Schoott var. Antiquorum) Pada Tikus Putih (Rattus norvegicus) Jantan Galur SPRAGUE DAWLEY. Skripsi. Falkultas Kedokteran Dan Ilmu Kesehatan Program Studi Farmasi.

Khasanah, Nur., 2016. Pengaruh Konsentrasi Polimer Karbopol 940 sebagai Gelling Agent Terhadap Sifat Fisik Emulgel Gamma-Oryzanol. Skripsi. Fakultas Kedokteran dan Ilmu Kesehatan Program Studi Farmasi. Jakarta.

Laverius, M.F., 2011. Optimasi Tween 80 Dan Span 80 Sebagai Emulsifying agent Serta Carbopol Sebagai Gelling agent Dalam Sediaan Emulgel Photoprotector Ekstrak Teh Hijau (Camellia sinensis L.) Aplikasi Desain Faktorial. Skripsi. Falkultas Farmasi Universitas Dharma.

Perdana Ss., I. 2011. Efek Pemberian Ekstrak Buah Mahkota Dewa (Phaleria macrocarpa) Terhadap Penurunan Derajat Eritmia Luka Bakar Derajat II Pada Tikus (Rattus novergicus) Galur wistar. Jurnal Ilmiah Berkala Universitas Kadiri, 21.

Astuti, D.D., 2012. Formulasi Sediaan Gel Ekstrak Etanolik Buah Mahkota Dewa (Phaleria macrocarpa (Scheff.) Boerl.) Dengan Basis HPMC.Naskah Publikasi. Falkultas Farmasi Universitas Muhammadiyah.

Armansyah, T., Balqis, U., Frengky, Azzahrawani, N., Hamdani, Aliza, D., 2016. Efikasi Mentimun (Cucumis sativus L.) Terhadap Percepatan Penyembuhan Luka Bakar 
(Vulnus combustion) Derajat IIB

Pada Tikus Putih (Rattus

novegicus). Jurnal Medika

Veterinaria, Vol 10(2). 